ECONOMIC THEMES (2020) 58(4): 545-571

S sciendo

DOI 10.2478/ethemes-2020-0031

\title{
ASSESSMENT OF THE ACCOUNTING REGULATIONS IN THE REPUBLIC OF SERBIA: APPLICATION OF CLUSTER ANALYSIS
}

\author{
Sunčica Milutinović \\ University of Novi Sad, Faculty of Economics in Subotica, Serbia \\ $\bowtie$ suncica@ef.uns.ac.rs \\ Olivera Grljević \\ University of Novi Sad, Faculty of Economics in Subotica, Serbia \\ 凶oliverag@ef.uns.ac.rs \\ Dragomir Dimitrijević \\ University of Kragujevac, Faculty of Economics, Serbia \\ $\square$ dimitrijevicd@kg.ac.rs
}

UDC

006.44:657

(497.11)

Original scientific paper

Received: 22.07.2020 Accepted: 29.09.2020

\begin{abstract}
The focus of the paper is on identification of hidden patterns in the opinion of accounting professionals, in order to identify the deficiencies in the legal accounting regulations and to examine their perspective on international and legal accounting regulations. The data collected through the questionnaire was divided using clustering data mining technique. We identified different groups of accountants with specific patterns regarding the expressed attitudes towards both regulations, as well as different groups of accountants with specific patterns regarding the way of obtaining information. The findings point to the prevailing negative attitude towards the legal accounting regulations quality, and differences in the habits and attitudes of certified and non-certified accountants, i.e. accountants who (don't) use International Financial Reporting Standards. Since there are four developed models, we used them as a basis for proposing a model of information seeking that could mitigate negative views on accounting regulations in the national economy. The key points of the proposed model are the introduction of compulsory continuous professional education and certification of all accountants, as well as activities for the popularization and accessibility of the international accounting regulations.
\end{abstract}

Keywords: International Financial Reporting Standards, accounting regulations, quality, accountants, clustering, data mining

JEL classification: M41, M48, C38 


\section{Introduction}

By 2025, the European Union (hereinafter: EU) could exceed the number of 27 members. Accession negotiations are already well underway with the two most advanced candidates in the Balkans - Montenegro and Serbia. With strong political will and the delivery of real and sustained reforms, including the financial reporting reform, they could be ready for the membership in 2025 perspective. This time frame for the realization of reforms is rather ambitious. Whether it will be achieved fully depends on the objective merits and results of each country (Commission 2018). In terms of financial reporting reform, experience and insights from the EU are of great relevance. The European Commission (Commission 2014) has conducted a public consultation on the effects of the application of International Financial Reporting Standards (hereinafter: IFRS) in the EU. The obtained results unambiguously indicate that the application of IFRS in the EU improved the transparency of companies' financial statements, contributed to a greater comparability, as well as improved the investor protection compared to what it was before mandatory adoption (more on results in Section 2).

Serbia, as the current front-runner in the process of joining the EU, is in the midst of the extensive reforms that include measures to modernize and strengthen the national economy. The aim of the reform is to support Serbia in the process of joining the EU. The reform of corporate financial reporting is a part of these measures, and it ultimately results in the development of high-quality financial reporting in accordance with the EU Acquis Communautaire and international accounting regulations (hereinafter: IAR). Some of the measures include capacity building in the accounting and auditing profession, as well as improving the monitoring and evaluation of the application of IFRS in the private and public sector by the financial reporting regulator.

Serbia lacks legal accounting regulations (hereinafter: LAR) and those that do exist are not fully compliant with the applicable accounting regulations in the EU (primarily Directive 2013/34/EU, but also IFRS provisions). The areas with noticed discrepancies are: the quality control of financial statements, the responsibility for the preparation, the presentation and disclosure of financial statements, the content of the compulsory set of financial statements, the extensiveness of financial statements, the reporting bases, the status and position of certified accountants, the ethical issues, and professional education (Milutinović, 2014). With the adoption of the new Law on Accounting (Ministry of Finance of the Republic of Serbia, 2019) and the new Law on Auditing (Ministry of Finance of the Republic of Serbia, 2019) many areas have been harmonized and the law has never been closer to the Directive 2013/34/EU, but there are still fields for further improvements.

The research described in this paper is part of a more comprehensive study (Milutinović, 2016), which deals with the harmonization of financial reporting in Serbia. The harmonization is considered from the aspect of the degree of compliance 
of LAR with EU regulations in the field of accounting and financial reporting. In this paper, we deal with the issue of quality of IAR and LAR and the opinions of the accountants on this issue, as well as the issue of obtaining information on amendments to IAR and LAR. A negative attitude of accountants towards reforms and changes to LAR was identified in Serbia (Milutinović, 2014; Malinić, Novićević, Malinić, \& Stojanović, 2016; Milutinović, 2016), which complicates the process of harmonization of legal and EU regulations and makes their practical implementation difficult. Furthermore, this can be characterized as one of the main aggravating factors of regulatory harmonization of financial reporting in Serbia.

The purpose of the research presented in this paper is to provide the information seeking model that will reduce accountant's negative attitudes towards the reforms of accounting regulations in the countries joining the EU. The model is designed on the basis of the current opinion and habits of accountants in Serbia in the field of obtaining information on changes and novelties in the accounting regulations. For these purposes, two subsets of data were created and analysed using clustering data mining technique, the first with a focus on the attitudes of the profession on the regulatory framework, and the second with a focus on how accountants seek information about the accounting regulations. The main findings clearly distinguished the groups of accountants with:

- Different attitudes towards the quality of IAR and LAR, depending on whether the entity, with which they are employed, is an IFRS user or not, and

- Different patterns of obtaining information that depend mainly on the position of an accountant in the entity, a professional title, and whether the entity is an IFRS user or not.

The paper is organized as follows: Section 2 provides an overview of relevant literature, as well as the regulatory frameworks that address the issue of financial reporting; Section 3 describes the approach to data collection and data mining methods and techniques used in their analysis; Section 4 gives an overview of the results of clustering and summarizes the ways in which the profession in Serbia evaluates the regulatory framework; Section 5 provides an overview of clustering results on the way in which accountants in Serbia seek information about the accounting regulations. The conclusions and future directions of the research are presented in the last section of the paper.

\section{Related work}

The literature review is organized into two subsections. In the first we discuss the current research on the evaluation of accounting regulations in Serbia and the EU. As the clustering technique is the central method of our research, in the second subsection we discuss applicability of data mining techniques in the accounting domain and research related to ours. 


\subsection{Evaluation of accounting regulations}

Accounting regulations represent a relatively new research area with a special attention paid by international accounting regulatory bodies and professional organizations. Scientific literature overview has shown that there is a lack of scientific papers on accountants' attitude about the quality of accounting regulations in Serbia and other countries joining the EU. Our paper aims to address this issue and contribute to the current body of work. The research on the accounting regulations in Serbia was not conducted prior to 2014. The research presented in our paper is a part of a more comprehensive study that is also the first of this kind in Serbia (Milutinović, 2016), followed by a research study of the Serbian professional organization (Malinić, Novićević, Malinić, \& Stojanović, 2016). In the mentioned context, the following papers and studies especially testify to the scientific and professional elaboration of the analysed issue.

The study of Association of Accountants and Auditors of Serbia (Malinić, Novićević, Malinić, \& Stojanović, 2016), created based on the analysis of attitudes of certified accountants on the existing regulatory framework and the quality of financial reporting, was aimed at examining the actual situation in this field from the perspective of certified accountants who are greatly informed on current problems. The identification of weak points in the field of adoption of LAR, the application of IAR and the training of certified accountants was the second goal of the research study. The third goal was to provide constructive support to regulatory institutions in the process of adopting new LAR. At the end of the study, the following key positions of certified accountants were observed: poor legal solutions and non-updated translation of IAR led to the jeopardized public interest and deteriorated profession; given the undeniable advantages of IAR application, all reporting entities should be allowed to apply IFRS, regardless of the character of their classification by size; finally, the specific improvements of LAR in the domain of reporting bases, charts of accounts, delivery deadlines, signing and control of financial statements have been proposed. At the end of each year, the International Federation of Accountants conducts the research on the challenges faced by small and medium-sized entities around the world. The latest study carried out at the end of 2016 (International Federation of Accountants, 2016) showed that most of the entities in Europe (47\%) stated that their biggest challenge in business was keeping pace with new regulations and standards.

The European Commission (Commission, 2014) conducted a public consultation on the effects of the application of IFRS in the EU in order to seek the opinion of all stakeholders on Regulation no. 1606/2002 (The European Parliament and the Council of the EU et al., 2004). The objective was to assess the actual effects of IFRS, to what extent the initial objectives of the Regulation are met, whether these objectives are still relevant and whether there are areas for the improvement. After the public consultation, the European Commission concluded 
that the key objectives of Regulation no. 1606/2002 were met. The evidence suggests that the existing scope of the Regulation and the options given to the Member States are appropriate. The Commission supports IFRS as global standards and continues to invite the US Securities and Exchange Commission (SEC) to adopt IFRS to be used by domestic companies. The effectiveness and efficiency of the Regulation depends on the quality of the standards themselves, which should still be adequately assessed during their development and adoption (Deloitte Global Services Limited, 2018). The results showed that most of the respondents (86\%) think that the application of IFRS in the EU improved the transparency of companies' financial statements compared to situation before mandatory adoption. Most of the respondents think that the introduction of IFRS contributed to a greater comparability at the national, EU, and global level $(70 \%$, $92 \%$, and $79 \%$ respectively) compared to situation before mandatory adoption. More than two thirds of the respondents (71\%) state that the introduction of IFRS improved the investor protection through better information and stewardship by the management. Around a third $(32 \%)$ of the respondents believes that IFRS improved the investor protection to a great extent.

\subsection{Application of data mining in the accounting domain}

The applicability of the data mining methods and techniques in the domain of accounting was confirmed by numerous studies, out of which the following papers are especially emphasized. Alpar and Winkelsträter (2014) indicate the efficiency of data quality control by setting and applying clearly defined business rules. However, as many business situations and possible problems in the quality of data, arise, but cannot be determined in advance, the authors are considering the possibility of using data mining techniques in overcoming such unknown and undefined situations. They employ data mining to accounting transactions, in order to discover the patterns of data handling. The discovered patterns are represented in the form of association rules. The deviations from the discovered patterns point to potential data quality breaches that need to be addressed. Argyrou and Andreev (2011) suggest that accounting databases can be clustered in homogeneous and well-separated clusters that can be interpreted within an accounting context. Their further investigations reveal that clustering can compress a large number of similar transactions, and also provide information comparable to that of financial statements. Thiprungsri and Vasarhelyi's (2011) study examines the application of cluster analysis in the accounting domain, in particular its application to discrepancy detection in the field of audit. The purpose of their study is to examine the use of clustering technology to automate fraud filtering during the audit. They use cluster analysis to help the auditors focus their efforts when evaluating group life insurance claims. Haga, Siekkinen, \& Sundvik (2015) are investigating the power of self-organizing map local regression-based estimation models in 
accounting. These models estimate the abnormal components of operating activities and financial reporting. An umbrella term for this is accounting quality.

A number of papers deal with the issue of assessment of accounting convergence (Carneiro, Rodrigues, \& Craig, 2017; Cascino \& Gassen, 2015; Chand \& Patel, 2008; Ding et al., 2007; Palacios-Manzano \& Martinez-Conesa, 2014; Peng \& van der Laan Smith, 2010; Rezaee et al., 2010; Socoliuc et al., 2012), and in some of them the authors deal with the development of new methods, based on the underlying concepts of data mining approaches, to measure advances in harmonization (Fontes, Rodrigues, \& Craig, 2005; Qu \& Zhang 2008). In Qu and Zhang (2008) the authors propose a new method of matching and fuzzy clustering analysis to assess the convergence progress of the latest China's accounting standards (hereinafter: CAS) with IFRS from the whole and single standards respectively. The research design adopted in this study demonstrates how fuzzy clustering analysis is applied to measuring formal accounting convergence using the example of CAS convergence with IFRS. They concluded that CAS achieved its goal of substantial convergence with IFRS from the whole. They also concluded that the new method of fuzzy clustering analysis cannot only assess the convergence progress of national accounting standards with IFRS from the whole, but can cluster single standards, according to their convergence level, and even indicate further convergence emphasis. To the best of our knowledge, the studies dealing with the assessment of accounting convergence, including Qu and Zhang's (2008) paper, did not take into account the experience and opinion of the profession, which deals with their application on a daily basis, in order to identify the aggravating aspects of the application of IFRS that slow down the adoption of IAR in practice, and the process of harmonization itself. The research presented in our paper takes into account the profession, while the results of the clustering of the surveyed accountants enabled us to draw the conclusions on the key problematic aspects of adopting IFRS in the country in the process of joining the EU and to propose the information seeking model that could mitigate the negative attitudes on accounting regulations in the Serbian economy and enable a more successful process of the harmonization of legislation.

\section{Materials and methods}

The subject of the research is the evaluation of IAR and LAR by the accountants, on the one hand, and the ways of informing about the changes and novelties, on the other hand. If we observe our overall objective from the financial reporting perspective, it could be formulated as a question: Why is the research conducted in the field of financial reporting? A research aims to complement the theoretical foundations with the results of empirical research in an area in which they are rare, particularly at national level. The main objective of the analyses presented in the paper is to comprehensively examine the attitudes of accountants according to the 
accounting regulatory framework, both legal and international. In addition to general attitudes, the research also covers the methods and frequency of information seeking by the profession about the changes and novelties in this field. The research questions are set in order to uncover the hidden patterns in the opinion of surveyed accountants on the quality of accounting regulatory framework, both legal and international, as well as to profile the accountants according to the way they obtain information on novelties and changes in the accounting regulations.

Research questions 1: Are there any differences in the attitudes of certified and non-certified accountants on the quality of both accounting regulatory frameworks?

Research question 2: Does the use of IFRS on daily basis determine the differences in accountants' habits of seeking information regarding accounting regulations and what are such differences?

The purpose of the research is to provide a feedback from the practice to the regulatory framework makers, who legally shape financial reporting. Furthermore, the research findings can help more effective overcoming of the problems that the practice is facing. The results of the research are significant, because the timely feedback from the practice is the key determinant of the well-created LAR, and thus the research is important not only for the creators of the regulatory framework, but also for other state bodies that (in)directly influence this area, accounting professionals, supervisory authorities and managing bodies in an entity. Večerskienè, Valančienė, and Boguslauskas (2008) suggest that accounting requires a constant research whose results facilitate: a) the formation of legal basis of accounting and accounting policy at both enterprise and state level, b) the correction and development of accounting standards, and c) the formation of accounting system for companies' management and study of their implementation.

The originality of the paper is reflected in the fact that a research similar to this has not been realized so far in domestic practice, and especially with the application of the clustering data mining technique. The scientific contribution of the research conducted in the paper is undeniable, bearing in mind that the field of financial reporting is very dynamic in terms of frequent changes in the regulations, both legal and international. In order to timely keep up with the novelties and the effects of changes in this field, a constant research is needed, especially in domestic practice, which in this area is unjustifiably absent. The limitation of the paper of an objective nature is the lack of similar research in Serbia and the region, in order to conduct parallel analyses and obtain a wider picture of this issue.

The remaining of the section is organized as follows. Section 3.1 describes in detail the data used in the research (sources, sampling, and collection methods). Section 3.2 describes the method used for data analysis, as well as the approach to results' evaluation. 


\subsection{Materials}

The research described in the paper was independently planned, projected, and realized by the authors using a set of data collected through the questionnaire (Milutinović, 2016). This method was selected because a questionnaire provides the best approach to the subject of the research - an assessment of the accounting regulations by professionals. The questionnaire structure and questions selection were performed using the Delphi method with ranking (Okoli \& Pawlowski, 2004) while respecting all the procedures in iterations (Hsu \& Sandford, 2007). The questionnaire contains fourteen questions of closed type and 41 categorical variables. The offered answers to the closed type questions were created using the categorical itemized rating scale: Likert (Croasmun \& Ostrom, 2011; Likert, 1932).

Table 1 - Sample structure

\begin{tabular}{|c|c|c|c|}
\hline Variables & Items & Frequency $(\mathrm{n}=338)$ & Percentage \\
\hline \multirow{5}{*}{$\begin{array}{l}\text { Position of } \\
\text { an } \\
\text { accountant }\end{array}$} & Accountant - chief executive officer & 18 & 5.33 \\
\hline & Accountant - chief financial officer & 24 & 7.10 \\
\hline & $\begin{array}{l}\text { Accountant - bookkeeping agency } \\
\text { owner }\end{array}$ & 63 & 18.64 \\
\hline & Accounting / audit manager & 93 & 27.51 \\
\hline & Accountant & 140 & 41.42 \\
\hline \multirow[t]{3}{*}{$\begin{array}{l}\text { Professional } \\
\text { title }\end{array}$} & $\begin{array}{l}\text { Issued by some domestic IFAC member } \\
\text { professional organization }\end{array}$ & 149 & 44.08 \\
\hline & $\begin{array}{l}\text { Issued by some foreign professional } \\
\text { organization }\end{array}$ & 41 & 12.13 \\
\hline & $\begin{array}{l}\text { Without professional title (non-certified } \\
\text { accountants) }\end{array}$ & 148 & 43.79 \\
\hline \multirow{4}{*}{$\begin{array}{l}\text { Work } \\
\text { experience }\end{array}$} & Below 1 year & 26 & 7.69 \\
\hline & Between 2 to 5 years & 67 & 19.82 \\
\hline & Between 6 to 9 years & 65 & 19.23 \\
\hline & More than 10 years & 180 & 53.25 \\
\hline \multirow{4}{*}{$\begin{array}{l}\text { Size of an } \\
\text { entity }\end{array}$} & Micro legal entity & 138 & 40.83 \\
\hline & Small legal entity & 103 & 30.47 \\
\hline & Medium-sized legal entity & 59 & 17.46 \\
\hline & Large legal entity & 38 & 11.24 \\
\hline \multirow{3}{*}{$\begin{array}{l}\text { Type of the } \\
\text { accounting } \\
\text { regulations }\end{array}$} & International & 82 & 24.26 \\
\hline & IFRS for SMEs & 89 & 26.33 \\
\hline & Legal (domestic legislation) & 167 & 49.41 \\
\hline
\end{tabular}

Source: Authors' calculation

Statistical population comprises accountants employed in the private sector of Serbia, regardless of their position, professional title, work experience and the size of entities in which they are employed. Data used in this research was collected through the questionnaire which was distributed electronically to 7,690 e-mail 
addresses in 2017. A total of 338 complete and valid responses were received within six months, which means that the response to the questionnaire was $4.4 \%$.

The sample in this research was chosen randomly, because each member of the population had equal chance, i.e. the same likelihood of being sampled. Furthermore, the selection of each sample member was independent, i.e. the choice of one member did not influence the choice of any other member of the sample. The question arises as to whether the sample size $\mathrm{N}=338$ is sufficient to carry out the research? The size of the sample should be $\mathrm{N}>(50+8 * \mathrm{~m})$ (Tabachnick \& Fidell, 2013), where $m$ is the number of independent variables. For the purposes of this research a total of 22 variables from the questionnaire was used, and thus $\mathrm{N}>$ $(50+8 * 22)$, i.e. the sample must be greater than 226 respondents. Since $N>226$ the condition of the minimum size of the sample is fulfilled. The sample structure is presented in Table 1.

In order to assess the reliability of the questionnaire, Cronbach's alpha coefficient will be applied (Nunnally, 1979), which shows how many variables (questions from the questionnaire) are positively correlated. It is considered that a questionnaire with multiple variables is reliable if all variables express the same phenomenon, but in a slightly different way. Cronbach's alpha coefficient was calculated for the 22 chosen variables used in this paper. Cronbach's alpha coefficient is 0.864 (Table 2), which means that the variables have a high internal consistency, i.e. reliability (Pavot, Diener, Colvin, \& Sandvik, 1991).

Table 2 - Questionnaire reliability assessment ${ }^{1}$

\begin{tabular}{ccc}
\hline & Reliability statistics \\
\hline Cronbach's alpha & $\begin{array}{c}\text { Cronbach's alpha based on } \\
\text { standardized items }\end{array}$ & Number of items \\
\hline 0.864 & 0.858 & 22 \\
\hline
\end{tabular}

Source: Authors' calculation based on IBM SPSS Statistics v.20

\subsection{Methods}

An important role in the search for useful and high quality information hidden in the large amounts of data belongs to data mining methods and techniques (Bošnjak et al., 2018). The collected data was analysed using clustering data mining technique. Clustering is a process by which a similarity of elements of a particular dataset can be determined (Bošnjak et al., 2018). It allows better understanding of complex data structures by grouping data in unsupervised way revealing hidden and unique patters within each group (Berkhin, 2006; Trninić et al., 2011). The

\footnotetext{
${ }^{1}$ Table 2 reports the result of Cronbach's alpha coefficient calculated for the 22 chosen variables. The reliability coefficient measured by Cronbach's alpha method of 0.70 or higher is considered acceptable in research in the field of social sciences. The maximum value of this coefficient is 1.
} 
process of dividing feature space vectors into groups, called clusters, is conducted in the self-organized mode where one cluster represents a group of points in a multi-dimensional space. The points aggregated in such a way are closer to each other and to their "cluster centre", i.e. centroid, than they are to the centres of other groups, meaning that one cluster comprises objects similar to each other and different from the objects of other clusters. By clustering the surveyed accountants, we tried to detect groups with similar "patterns", i.e. attitudes, and based on derived findings, to make recommendations for personalizing the approach to information seeking to the needs of different groups of accountants.

Clustering algorithms are broadly categorized on the basis of an algorithm underlying clustering criteria into (Nerurkar, Shirke, Chandane, \& Bhirud, 2018): partition-based clustering algorithms, fuzzy clustering, model-based clustering algorithms, and density-based clustering algorithms. Our research is based on partition-based approach to clustering. The general principle of partition-based clustering algorithms is that a cluster should contain at least one object and that each object must belong to exactly one cluster (Nerurkar, Shirke, Chandane, \& Bhirud, 2018). It can be defined as k-Means problem where integer $\mathrm{k}$ is given and a set of $\mathrm{n}$ data points $\mathrm{X} \subset \mathrm{R}^{\wedge} \mathrm{d}$ (Arthur \& Vassilvitskii, 2007). The number of clusters (k) is defined by the user/analyst and each $\mathrm{k}$ is represented by the so-called centroid. Centroid is usually the mean of a group of points belonging to a cluster and is typically applied to objects in a continuous n-dimensional space (Tan, Steinbach, \& Kumar, 2007). The goal is to choose $\mathrm{k}$ centre C and to minimize the potential function, i.e. to minimize the total squared distance between each point and its closest centre:

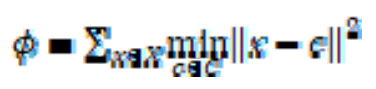

Clustering for each centre is implicitly defined by the choice of these centres, since one cluster is set to be the collection of data points that are closer to that centre than to any other, and finding an exact solution to the k-Means problem, even for two clusters, is NP-hard (Arthur \& Vassilvitskii, 2007).

Popular partition-based clustering algorithm is k-Means, which was used in the research presented in our paper. K-Means algorithm is the simplest and fastest solution to k-Means problem and it is the most popular clustering tool used in scientific and industrial applications (Berkhin, 2006). It begins with arbitrarily chosen $\mathrm{k}$ centres $\mathrm{C}=\left\{\mathrm{c} \_1, \mathrm{c} \_2, \ldots, \mathrm{c} \_\mathrm{k}\right\}$. Each data point in a dataset is then assigned to the nearest centre, and each centre is recomputed (Arthur \& Vassilvitskii, 2007). These steps are repeated until the overall process is stabilized and $\phi$ is minimized. In our research we used Weka's (Weka, 2019) implementation of simple k-Means algorithm.

One of the key issues regarding clustering is overcoming subjectivity regarding the number $\mathrm{k}$ of clusters provided by the user/analyst and determining the optimal 
number of clusters. Many strategies and criteria have been suggested to estimate the ideal number of clusters (Berkhin, 2006; Nerurkar, Shirke, Chandane, \& Bhirud, 2018; Quah, 2014; Yang \& Yuan, 2019), such as Elbow method and Silhouette Coefficient. These methods can be used separately or combined, where Elbow method is considered as a decision method or a decision rule, while Silhouette criterion is meant for validation. Therefore, for decision on optimal number of clusters, we employed Elbow method where $\mathrm{k}$ is the turning point on the graph of k v/s Avg. distance to centroid (Nerurkar, Shirke, Chandane, \& Bhirud, 2018; Syakur et al., 2018). The objective is to minimize the sum of squared distance or the potential function, as explained above.

\section{Profession's assessment of regulatory framework}

Dataset, used for the clustering models presented in Section 4.1 and Section 4.2, include the assessment of legal (domestic) and professional (international) accounting regulations. LAR in Serbia have been analysed based on: frequent changes in laws and regulations, discrepancy between laws and IAR, poor legal solutions and marginalization of the accounting profession. IAR were considered in the context of the following characteristics of IFRS: comprehensiveness, understandability, ease for use, extensiveness, a large number of alternatives, adequate translation into Serbian, and coverage of all the necessary aspects of compiling financial statements in Serbia.

Cluster analysis was carried out with the aim of comprehensive modelling of attitudes of accountants, in terms of quality of LAR and IAR. For these needs, in addition to the opinions of the respondents, data on the entity in which the respondent is employed and the position of the respondents in the entity were also included. The results of clustering indicate clear differences in the attitudes of the accountants about the quality of LAR and IAR, depending on the entity in which they are employed. The results of clustering and differences in attitudes are described in more detail in Section 4.1.

Due to the fact that all entities in Serbia do not use IFRS, entities are aggregated according to whether they are IFRS users or not (Ministry, 2017). Large entities using IFRS, medium-sized entities that have chosen to use IFRS and small entities that have chosen to use IFRS represent users of IFRS, while small and micro entities that use only domestic regulations represent a group of entities that do not use IFRS. The clustering model, described in Section 4.2, divides the respondents according to their opinions on LAR and IAR, and whether the entities, in which the respondents are employed, are IFRS users or not. The results indicate clear differences in the attitudes of accountants who are employed by an entity that is IFRS user in relation to accountants employed by entities that do not use IFRS. Results and a detailed overview of the differences in opinions are provided in Section 4.2. 


\subsection{Regulatory framework assessment - results of the first model}

Based on the described approach to evaluating the clustering model and determining the optimal number of clusters in Section 3.2, it was found that the best partitioning of accountants according to their title and attitude about LAR and IAR is achieved with five clusters. The results of clustering are shown in Figure 1. The value 0 of the qualification attribute indicates the absence of a professional title assigned by a professional organization, while the value 1 indicates the assigned title. For other attributes in Figure 1, the value 0 indicates that the respondent has no attitude on the given aspect, the value 1 indicates disagreement, the value 2 shows partial agreement, and the value 3 indicates the agreement of the respondent.

Figure 1 - Clustering of accountants according to their attitudes towards LAR/IAR

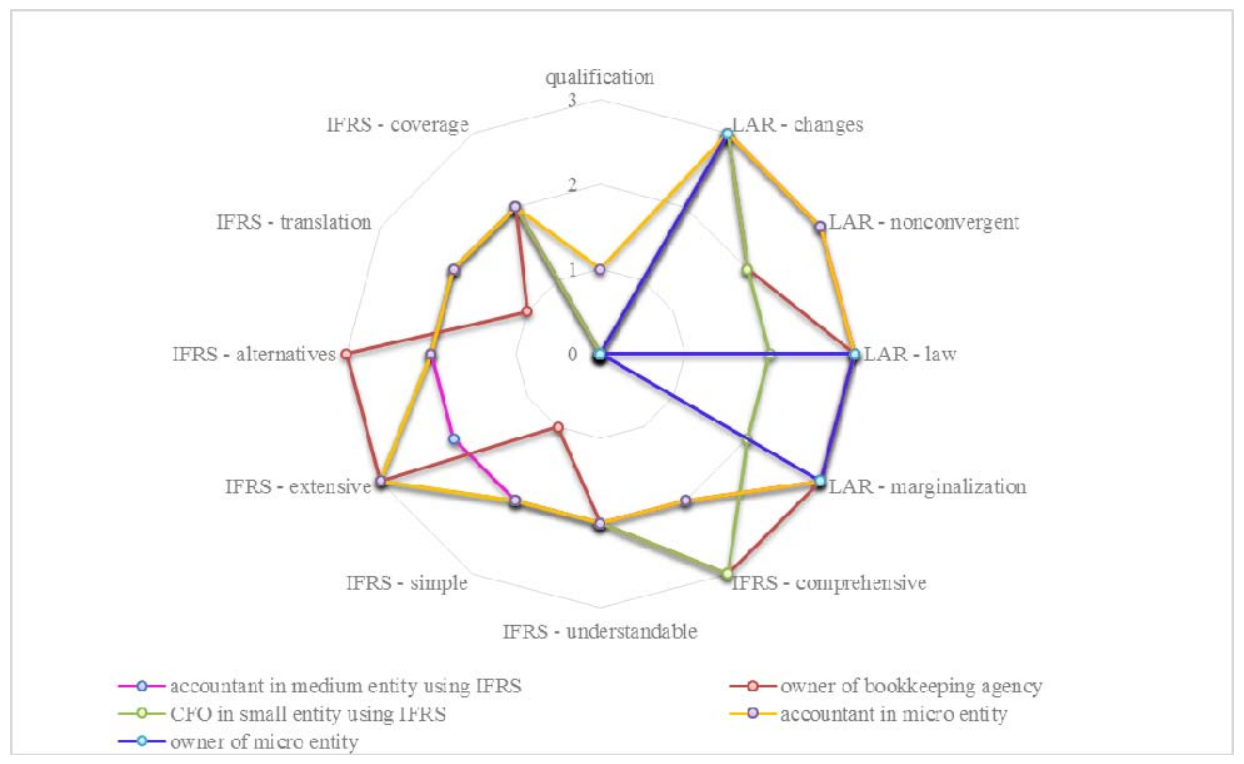

Source: Authors' calculation

Two clusters include accountants (persons in charge of compiling financial statements) employed with medium-sized entities that apply IFRS (Figure 1: accountant in medium-sized entity using IFRS) and in micro entities (Figure 1: accountant in micro entity). The accountants employed by micro entities predominantly hold a professional title assigned by a professional organization, while employees in medium-sized entities do not predominantly have a professional title. The accountants daily and directly apply LAR when preparing financial statements and as such are most competent to assess their quality. Based on the data structure in the clusters, it is concluded that these individuals share 
categorical opinions on the frequent changes in LAR, their non-compliance with IAR, poor legal solutions, and the marginalization of the accounting profession, regardless of the size of the entity in which they are employed (medium-sized entities that apply IFRS or micro entities).

Regarding IAR, the accountants partially agree with the above-mentioned aspects of IFRS, indicating their relative seriousness and complexity. The accountants employed by micro entities predominantly show a stricter attitude regarding the scope of these standards compared to the attitude of employees in the same position in medium-sized entities applying IFRS. This can be attributed to the diametrically different frequency of the application of IFRS by these two clusters. Namely, accountants employed in medium-sized entities more frequently apply IFRS and have acquired the habit of frequent IAR consultation in everyday transactions, unlike the professionals in micro entities. Besides, the conclusion stemming from the clustering results shown in Section 5 that employers are increasingly choosing to cut expenditure for vocational seminars, at this point explains the disparity in attitude rigidity of accountants from micro, i.e. mediumsized entities in terms of IFRS extensiveness. Namely, the expenses for professional seminars are the same regardless of whether the seminar participant (accountant) comes from a micro, small, medium-sized or large entity. Accordingly, and with regard to the fact that the total revenue is one of the three criteria for classifying entities, the conclusion is drawn that the smaller the entity, the greater the chances that it cannot fund professional seminars for its accountants, and vice versa. In this way, the professional seminars, as a way of obtaining information and education on IFRS, are more available to the accountants from the larger entities. The accountants from the micro entities are not sufficiently familiar with IFRS, both due to the lack of their active application, and due to the lack of education as they fail to attend the professional seminars, and therefore, they express a strong stance in terms of their extensiveness.

Chief financial officers (hereinafter: CFOs) in micro entities are predominantly the owners of bookkeeping agencies (Figure 1: the owner of bookkeeping agency), who do not have professional titles in their field. Including CFOs and the owners of bookkeeping agencies to research process is important. Their understanding of the need for IFRS adoption and the process of accounting regulations harmonization is the main prerequisite for strengthening the human capital in an entity through the support in professional education and professional certification of accountants. The more CFOs and owners of bookkeeping agencies are aware of importance of IFRS adoption and harmonization of accounting regulations, they are more likely to provide the accountants with the necessary conditions for training, as well as the necessary means to get up to date information on changes and novelties in the accounting regulations (providing training materials and professional literature, allocating funds for seminars, workshops, and certifications, etc.). 
The respondents, who belong to this cluster, believe that LAR are partially incompatible with IFRS, while taking a firm negative stance towards other aspects under which LAR are evaluated. Although they state that IFRS are comprehensive, the owners of bookkeeping agencies are of the opinion that they are not easy to implement and have been inadequately translated into Serbian. They also believe that these standards are not fully understandable and partly cover the necessary aspects of the preparation of financial statements in Serbia. This cluster represents the accountants with the highest objections to IFRS, i.e. according to the aspects by which IFRS are evaluated; they more strongly assess them than the accountants belonging to other clusters. The reasons for the stated attitudes of the respondents of this cluster can be the following:

- Insufficient knowledge about IFRS (which is explained by the fact that they do not have professional titles);

- Lack of education on IFRS (which is explained by the fact that they do not attend professional seminars);

- Absence of IFRS application (their clients are most often the submitting entities of only LAR), and

- Leading position in an entity (more often they perform management, coordination, and delegation tasks, and rarely are referred to the direct application of IFRS through the execution of operational tasks).

CFOs in small entities using IFRS (Figure 1: CFO in small entity using IFRS) take a somewhat negative attitude towards LAR, except in the case of amendments to laws and regulations that they consider to be frequent. Their attitude to LAR is milder, but they are less competent than the accountants from the first two described clusters. The reason for this is the fact that CFOs in small entities do not apply or do not apply often and thoroughly LAR in everyday transactions, as the accountants do. The members of this cluster more often use IFRS in practice, and are most competent to evaluate IAR. Based on the data and cluster structure, it can be concluded that they share opinions with the owners of bookkeeping agencies about the comprehensiveness of international standards, their extensiveness, partial understandability, as well as that IFRS partly cover the necessary aspects of the preparation of financial statements in Serbia. Unlike CFOs in micro entities (i.e. the owners of bookkeeping agencies), they do not consider IFRS to be complex, nor inadequately translated. This stance can be attributed to the fact that CFOs in small entities, due to more frequent implementation of IFRS in practice, are more comfortable with their use and have become accustomed to the terminology.

The last cluster consists of owners of micro entities who apply LAR, but are not familiar with or do not use IFRS, i.e. IAR (Figure 1: the owner of micro entity). The data clearly indicate that they do express neither a positive nor a negative attitude towards IFRS, nor in terms of compliance of LAR with IAR. On the other hand, they take a firm negative attitude towards LAR, like the accountants from the 
first two described clusters, because they are familiar with LAR as they apply it on a daily basis. Therefore, the members of these three clusters agree that LAR are characterized by frequent changes to the law and the existence of poor legal solutions, and thus such legal solutions lead to the marginalization and impairment of the accounting profession in Serbia.

\subsection{Regulatory framework assessment-results of the second model}

Based on the described approach to evaluating the clustering model and determining the optimal number of clusters in Section 3.2, it was discovered that the best partitioning of accountants according to their position, according to whether the entity which employs them uses IFRS or not, and according to the stance they have taken towards LAR and IAR, is also achieved with five clusters. The results of clustering are shown in Figure 2. Attribute type assumes value 1 when the observed entity uses IFRS, while value 2 indicates entities that do not use IFRS. Three positions of the respondents appear among the typical representatives of the created clusters: 1 - accountant, 2 - CFO, and 3 - owner. Attribute qualification assumes value 1 when the respondent is certified, and 0 when the respondent is non-certified. For other attributes, value 1 denotes disagreement of the respondents, value 2 is partial agreement, value 3 denotes agreement, and value 0 signifies that the respondent has no attitude towards the given aspect. The first three clusters describe representatives of entities using IFRS, while the last two describe representatives of entities that do not use IFRS.

Figure 2 - Clustering of accountants employed in entities using/not using IFRS, according to their attitude towards LAR/IAR

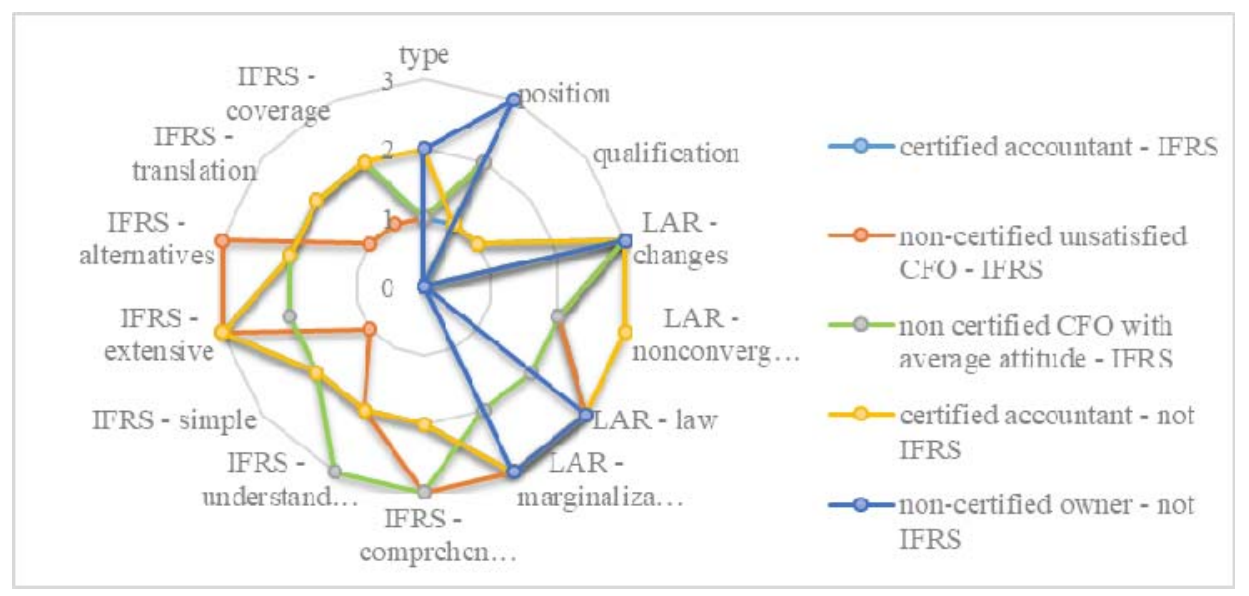

Source: Authors' calculation 
The first cluster predominantly includes certified accountants employed with an entity using IFRS (Figure 2: certified accountant - IFRS), who have a negative attitude towards LAR in Serbia. They consider it to be characterized by frequent changes, poor legal solutions, and marginalization of the accounting profession. The respondents of this cluster show partial agreement on the evaluated aspects of IFRS, while they express an absolute agreement only when it comes to the extensiveness of IFRS.

The second (Figure 2: non-certified unsatisfied CFO - IFRS) and the third cluster (Figure 2: non-certified CFO with average attitude - IFRS) consists mainly of non-certified CFOs employed by an entity that is an IFRS user. The respondents of the second cluster have more clearly defined attitudes regarding the evaluated aspects compared to the third cluster respondents, but also the most complaints about IAR among the observed clusters. Partial agreement is expressed towards the non-compliance between LAR and IAR and the comprehensibility of IFRS, while they show a pronounced negative attitude towards LAR, believing that it often changes, that the legal solutions are poor and thus the accounting profession is marginalized. On the other hand, members of this cluster, although believing that IFRS is comprehensive and have a number of alternatives, they negatively evaluate IFRS considering it to be extensive, complicated for implementation, inadequately translated into Serbian, and that they do not cover all the necessary aspects of compiling financial statements in Serbia. The members of the third cluster show a strong attitude towards frequent changes to laws and regulations, while expressing a positive attitude towards IFRS assessing it to be comprehensive and comprehensible. The respondents of this cluster partly agree with all other aspects on which domestic IAR are evaluated, which makes them members of the cluster with the least objections in relation to both observed regulations.

The respondents grouped in the fourth cluster are predominantly certified accountants employed in an entity that does not use IFRS (Figure 2: certified accountant - not IFRS). Their attitude towards LAR in Serbia is the most negative one - they explicitly agree on all the evaluated aspects. It can be concluded that the more respondents are instructed to use LAR, the more negative attitude they have towards LAR. The respondents of this cluster share opinions on IFRS with respondents of the first cluster. This can be explained by the fact that members of the first and the fourth clusters have the same professional titles, attending the same seminars and education on IFRS and reading the same publications on IAR.

The fifth cluster primarily includes non-certified owners of bookkeeping agency that does not use IFRS (Figure 2: non-certified owner - not IFRS). These respondents do not have any opinion on IAR, or in terms of compliance between LAR and IAR, but they express a markedly negative attitude towards LAR. They use LAR in the widest and most frequent manner, but they are not familiar with nor do they use IFRS, which can explain their opinions. 


\section{Accountants' sources of information on accounting regulations}

Possible sources of information on amendments to laws and by-laws in the field of accounting, as well as novelties in the field of IFRS and other forms of IAR are professional seminars, the internet, professional publications and printed editions, and communication with colleagues from the same profession. For the purposes of research described in the paper, in addition to data on the frequency of use of these sources of information, data on employees' position in the entity, their professional title, as well as the size of the entity are also included.

In order to comprehensively examine the situation in professional practice regarding the method of obtaining information about changes and novelties in the accounting regulations, two models have been developed using clustering techniques. The first model groups respondents according to their position in the entity and sources of information about amendments in laws and by-laws in the field of accounting, as well as novelties in the field of IFRS and other forms of IAR. The results of clustering indicate that accountants show different patterns of obtaining information, depending on their position and whether they are certified. Furthermore, by ways of obtaining information, we can identify two categories of certified accountants: those who actively seek information by the maximum use of all available resources and those who only occasionally use available resources. The clustering results are described in more detail in Section 5.1. In order to closely examine the patterns of accountants' behaviour in informing about changes and novelties in accounting regulations, we have expanded the second model so that, besides the attributes covered by the first model, it includes the size of the entity in which the respondents are employed. Entities and their sizes are considered twofold: entity is an IFRS user and entity that does not use IFRS. We have discovered that the behaviour of accountants varies considerably depending on the entity in which they are employed, their positions, and whether they are certified. The clustering results are described in more detail in Section 5.2.

\subsection{Accountants' sources of information - results of the first model}

Based on the described approach to evaluating the results of clustering in Section 3.2 , it was discovered that the best partitioning of accountants according to their position and the frequency of using different sources of information about changes or novelties in the field of accounting is achieved with four clusters. Figure 3 illustrates the results of clustering. Values on Y-axis indicate the frequency of using certain sources of information about changes or novelties: 1 - sometimes, 2 frequently, 3 - always.

The persons in charge of compiling financial statements, i.e. non-certified accountants (Figure 3: non-certified accountants) do not seek information continuously; therefore they do not have permanent sources of information. Based 
on the data presented in Figure 3, it can be concluded that professional seminars are less used in relation to other sources of information, which can be explained by the fact that non-certified accountants do not have the obligation of continuous professional education (hereinafter: CPE) through seminars, and seminars are not an option for them due to high registration fees for those without membership in professional organizations, which are usually the organizers of these seminars.

Figure 3 - Clustering of accountants according to utilized sources of information on changes and novelties in the accounting sector

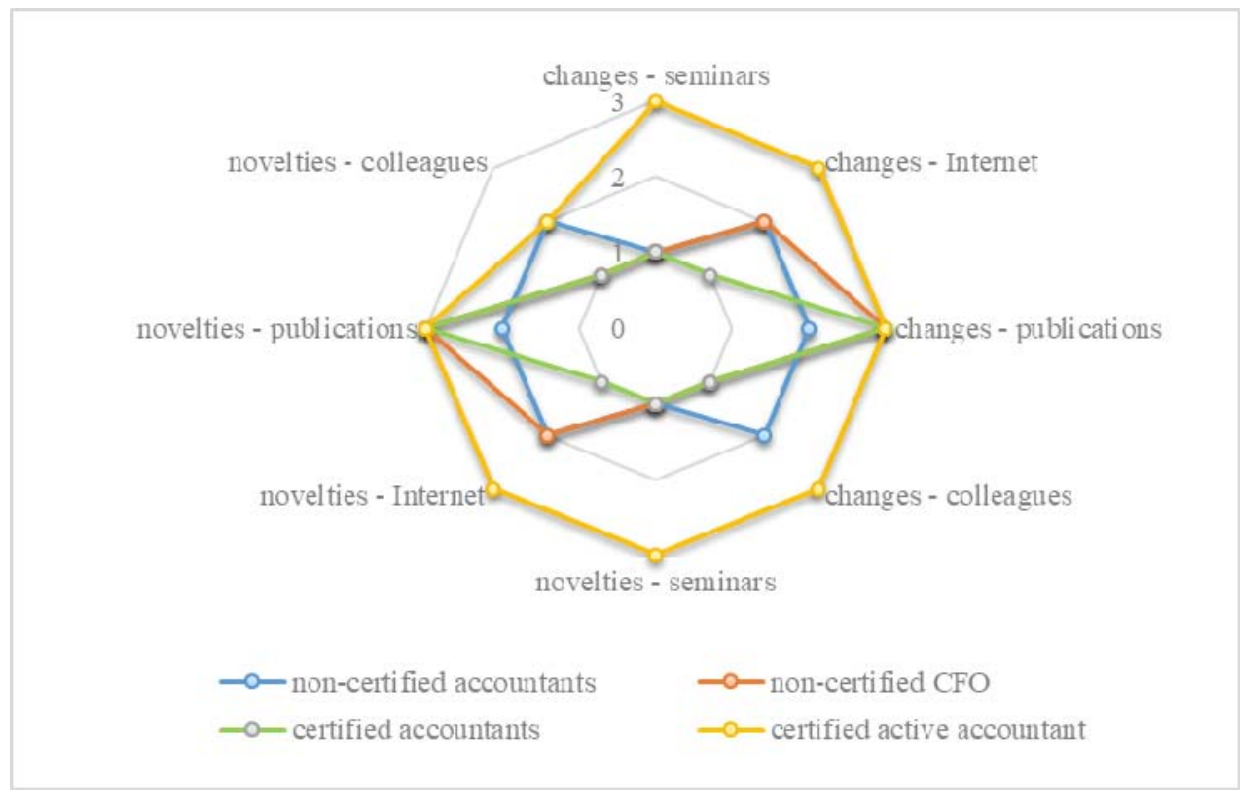

Source: Authors' calculation

Non-certified CFOs (Figure 3: non-certified CFO) sometimes consult their colleagues from the practice and sometimes attend professional seminars with the intention of informing themselves about changes in LAR or novelties in IAR. The reasons for poor attendance at seminars are similar to those of non-certified accountants. Unlike accountants, CFOs rarely consult with other colleagues, which may be the consequence of the superintendence of the position held by CFOs and the fact that they are superior to accountants. The basic sources of their information are professional publications and the internet.

The persons in charge of compiling financial statements i.e. certified accountants (Figure 3: certified accountants) always use professional publications as a basic source of information, while they sometimes use other sources of information. Namely, the professional publications are available for free or at 
affordable prices, given their membership in a professional organization by which they are certified. On the other hand, they have a CPE obligation, which explains their continuous consultation of professional publications. Furthermore, taking exams for higher professional titles implies preliminary preparation from professional publications. Although professional seminars are financially more accessible to non-certified accountants, they are not their most frequent source of information because their employers are increasingly choosing to cut these expenses in the conditions of overall savings measures in the Serbian economy.

Unlike other clusters, in which equal patterns are expressed for the way of informing about changes in LAR and novelties in IAR, members of the last cluster (Figure 3: certified active accountants) are the only one who rarely consult colleagues about the novelties on IAR, while they always consult them on LAR. Given their observed behaviour in terms of frequency and sources of information, it can be concluded that these are certified accountants employed in bookkeeping agencies. In their work, they use LAR more often than IAR because their clients are entities that do not have the obligation to apply IAR. This can explain the reason why they rarely consult colleagues when it comes to novelties in IAR. This cluster represents the most active accountants who maximally use all available sources of information. Since they are employed in bookkeeping agencies, they must have much broader professional knowledge and experience than other accountants, because they daily meet with the highly heterogeneous accounting needs of numerous clients of different sizes, coming from different areas, performing different business activities, and having different transactions, accounts, and bookkeeping needs. For these reasons, this cluster has to monitor the changes in LAR and IAR almost daily on the internet and in professional publications, printed editions, and visits to expert seminars. An intensive obtaining of information is particularly expressed in the tax accounting periods/quarters and at the end of the business year when annual financial statements are prepared for a large number of clients with heterogeneous needs.

\subsection{Accountants' sources of information - results of the second model}

Based on the described approach to evaluating the results of clustering in Section 3.2 , it was found out that the best partitioning of accountants according to their position, professional title, the size of entity with which they are employed, and the frequency of using different sources of information about changes or novelties in the field of accounting is achieved with five clusters. Figure 4 illustrates the results of clustering, while the values of clustering attributes are presented in Table 3. 
Table 3 - Keys for interpreting values in Figure $4^{2}$

\begin{tabular}{ccccc}
\hline Value & Type of legal entity & Position & $\begin{array}{c}\text { Professional } \\
\text { title }\end{array}$ & $\begin{array}{c}\text { Changes or novelties } \\
\text { (seminars, internet, } \\
\text { publications, colleagues) }\end{array}$ \\
\hline 0 & - & - & not certified & - \\
1 & using IFRS & accountant & certified & sometimes \\
2 & not using IFRS & CFO & - & often \\
3 & - & owner & - & always \\
\hline
\end{tabular}

Source: Authors' calculations

Figure 4. Clustering of accountants employed in the entities using/not using IFRS, according to utilized sources of information on changes and novelties

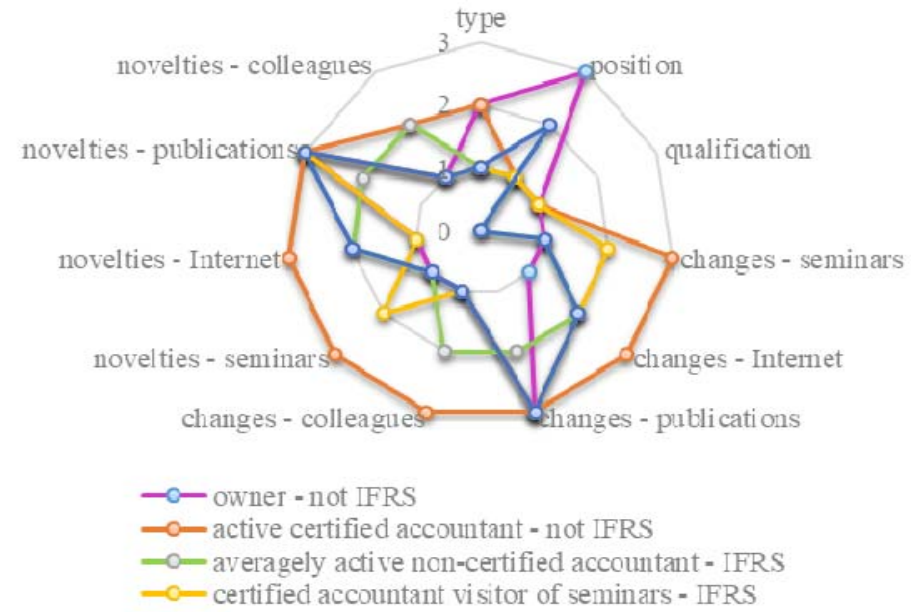

Source: Authors' calculations

The first cluster (Figure 4: owner - not IFRS) comprises certified accountants owners of bookkeeping agency that does not use IFRS. These are the accountants who use professional publications as the main source of information about the changes and novelties, while they occasionally use other sources of information. For the owners of bookkeeping agencies, the professional publications are a sufficient source for keeping the track of changes and novelties in the regulation, and it can be assumed that they do not use other sources of information often,

2 Table 3 reports the keys for interpreting the values of the following attributes: the type of legal entity, the position of accountant in the legal entity, the professional title of an accountant, and the frequency of using different sources of information about changes or novelties in the field of accounting. These keys are used for interpreting the values in Figure 4. 
because they, as the owners, do not record the daily transactions of the clients of their agency, because it is done by the accountants they hired.

The second cluster (Figure 4: active certified accountant - not IFRS) comprises certified accountants employed with an entity that does not use IFRS. They always use all sources of information, but they rarely decide to consult their colleagues about novelties and changes. Members of the second cluster, unlike members of all other clusters, are very active in obtaining information on accounting regulations. Since they only use LAR in their work, the intensity of obtaining information can be explained by frequent amendments to laws and by-laws in this field in the last few years.

The third cluster (Figure 4: averagely active non-certified accountant - IFRS) comprises non-certified accountants employed with an entity that uses IFRS. The cluster includes many active accountants who frequently use all sources of information, while they attend professional seminars from time to time because they are not mandatory for non-certified accountants, and they are not affordable for the accountants without membership in a professional organization that is organizing a professional seminar. Membership can be conditioned by a title of qualified accountants, which depends on organization, but almost all members of some professional organizations have a title. On the other hand, since they actively use IFRS, the accountants are maximally exploiting all other ways of informing about changes and novelties on LAR and IAR.

The fourth cluster (Figure 4: certified accountant visitor of seminars - IFRS) comprises certified accountants employed with an entity that uses IFRS. Their most frequent source of information about changes and novelties are publications published by a professional organization. They often visit professional seminars, probably because they are obligatory in the program of CPE. The internet is often used for obtaining information about changes, sometimes it is used as a source of information about novelties, while the colleagues are consulted only occasionally. Given that all other sources of information on changes and novelties on IFRS are available to them, the consultation with colleagues is the least represented.

The fifth cluster (Figure 4: non-certified CFO - IFRS) comprises non-certified CFOs employed with an entity that uses IFRS. As a basic source of information on changes and novelties, they use professional publications and the internet, while they periodically visit professional seminars and consult with their colleagues. Unlike the accountants, CFOs rarely consult with other colleagues, which may be the consequence of the superintendence of the position held by CFOs and the fact that they are superior to the accountants, which was also observed in previous clustering (CFOs from the second cluster). By comparing clusters, it can be concluded that non-certified employees use seminars the least for obtaining information, while most of them, for this purpose, use the internet and professional publications. 


\section{Conclusions}

The focus of this paper is the application of clustering data mining technique, in order to identify the hidden patterns in the behaviour of surveyed accountants about the way they obtain information on novelties and changes in the accounting regulations, as well as to profile accountants according to their opinions on the quality of LAR and IAR. The derived findings point to the prevailing negative attitude towards LAR quality, on the one hand, as well as the differences in the habits and attitudes of certified and non-certified accountants, i.e. the accountants who use and do not use IFRS in their work, on the other hand.

Four models of clustering were developed over the data collected through the questionnaire. The results of clustering reveal that certified accountants employed in an entity that uses IFRS are most informed about novelties and changes in accounting regulations, while the respondents holding managerial positions in an entity that does not use IFRS are informed the least. The higher the position of respondents in the entity and the more frequent use of other types of information, the less frequent is the consultation with colleagues on novelties and changes in the regulations.

The most competent evaluations of LAR come from certified accountants and owners of bookkeeping agencies that exclusively apply LAR in their work. Their opinions on LAR are fairly consistent. The dissatisfaction with LAR is almost certainly not affected by whether a respondent is certified or not, nor the size of an entity. However, the dissatisfaction is slightly higher in the respondents who hold lower positions in the entity, i.e. who directly apply the provisions of LAR on a daily basis. On the other hand, certified accountants and CFOs employed in entities that use IFRS are most competent to evaluate the offered aspects of IAR. Based on the opinions and assessments of members of these clusters, the recommendations for both types of accounting regulations have been provided below.

The key views emerging from the study (Malinić, Novićević, Malinić, \& Stojanović, 2016), and also important in terms of drawn conclusions in this paper are: the low level of financial reporting quality is due to inadequate legal solutions, frequent changes to laws, and inadequate translations of IFRS; non-compliance between LAR and IAR in terms of the forms of financial statements leads to their incomparability; quality financial reporting requires compulsory CPE of accountants. The key findings of the evaluation, which started in August 2014 (Commission, 2014), show that IFRS are successful in creating a common accounting language for capital markets. Respondents stated generally positive experiences with regard to the application of IFRS and in most cases the benefits outweighed the costs. Investors largely supported IFRS to improve the transparency and comparability of financial statements. These findings support the recommendations below and the proposed model of information seeking that follows. 
LAR should be changed in terms of introducing professional titles for all persons involved in accounting and auditing, which would eliminate the problem of marginalization of the accounting profession. The changes should include the introduction of compulsory $\mathrm{CPE}$, which would bring the regulation closer to its users. Training materials, professional education, examinations for obtaining professional titles and professional seminars for CPE should be charged at prices that would be acceptable to micro entities. Prices should be known in advance, should be transparent, and presented in a single pricelist, unless the above mentioned materials could be provided for free. By taking into account the opinions of users of regulations and the results of empirical research in this field when adopting new legal solutions, frequent amendments to LAR would be avoided. Changes to LAR should only be justified in cases where it would be necessary to align them with IAR. Up-to-date, timely, and adequate translation of IFRS, as well as free access to publications, other printed editions, and online materials for monitoring changes and novelties in IAR, is the condition to avoid prejudices arising from the insufficient information on IFRS. The popularization of IFRS for small and medium-sized entities to those entities that have the freedom to choose accounting regulation (these are micro and medium-sized entities in Serbia) would change users' opinion on the scope and complexity of IAR. The programs of professional seminars for CPE should equally include the elements of both accounting regulations - legal and international. In this way, the erroneous opinion in Serbia would be changed that LAR has an advantage over IAR.

The research presented in the paper was carried out to generate a proposal of a model of information seeking that would reduce the negative attitudes in the assessment of accounting regulations in the business environment of the country in the process of joining the EU. Given the above, the mentioned information model would contain the following elements:

- Obligation to certify all accountants in the practice and the availability and affordability of training materials, professional training, and possibility to take exams for professional titles;

- Obligation to introduce CPE and the affordability of attending professional seminars for this purpose;

- Up-to-date, timely, adequate, and publicly available translation of IFRS;

- Activities to popularize the application of IFRS using good practice examples from developed countries.

Future directions of the research would be that the same or similar research is repeated after at least two of four listed elements are fulfilled in the business environment that comprise the proposed model of information seeking, or after the country joined the EU. 


\section{References}

Alpar, P., \& Winkelstrater, S. (2014). Assessment of data quality in accounting data with association rules. Expert Systems with Applications, 41(2014), 2259-2268.

Argyrou, A., \& Andreev, A. (2011). A Semi-supervised Tool for Clustering Accounting Databases with Applications to Internal Controls. Expert Systems with Applications, 38(2011), 1117611181. https://doi.org/10.1016/j.eswa.2011.02.163

Arthur, D., \& Vassilvitskii, S. (2007). K-Means++: the Advantages of Careful Seeding. In: Proceedings of the Eighteenth Annual ACM-SIAM Symposium on Discrete Algorithms (pp. 1027-1025). https://doi.org/10.1145/1283383.1283494

Berkhin, P. (2006). A Survey of Clustering Data Mining Techniques. In: Grouping Multidimensional Data (pp. 25-71). https://doi.org/10.1007/3-540-28349-8_ 2

Bošnjak, Z., Grljević, O., \& Dimitrijević, M. (2018). Primena inteligentnih tehnologija u visokom obrazovanju. Anali Ekonomskog fakulteta u Subotici, 54, 291-303.

Carneiro, J., Rodrigues, L. L., \& Craig, R. (2017). Assessing International Accounting Harmonization in Latin America. Accounting Forum, 41, 172-184. https://doi.org/10.1016/j.accfor.2017.06.001

Cascino, S., \& Gassen, J. (2015). What Drives the Comparability Effect of Mandatory IFRS Adoption? Review of Accounting Studies, 20(1), 242-282. https://doi.org/10.1007/s11142014-9296-5

Chand, P., \& Patel, C. (2008). Advances in Accounting, Incorporating Advances in International Accounting Convergence and Harmonization of Accounting Standards in the South Pacific Region. Advances in Accounting, 24, 83-92. https://doi.org/10.1016/j.adiac.2008.05.002

Commission, E. (2014). Effects of Using International Financial Reporting Standards (IFRS) in the EU: Public Consultation [WWW Document]. [online] Available at: http://ec.europa.eu/finance/consultations/2014/ifrs/index_en.htm [Accessed in December 2019].

Commission, E. (2018). Communication from the Commission to the European parliament, the Council, the European economic and social committee and the Committee of the regions [WWW Document]. [online] Available at: https://ec.europa.eu/commission/sites/betapolitical/files/communication-credible-enlargement-perspective-western-balkans_en.pdf [Accessed in April 2020].

Croasmun, J. T., \& Ostrom, L. (2011). Using Likert-Type Scales in the Social Sciences. Journal of Adult Education, 1(40), 19-22. https://doi.org/10.1007/s10640-011-9463-0

Deloitte Global Services Limited (2018). European Commission Concludes Evaluation of the IAS Regulation [WWW Document]. [online] Available at: https://www.iasplus.com/en/news/2015/06/ias-regulation [Accessed in May 2020].

Ding, Y., Hope, O. K., Jeanjean, T., \& Stolowy, H. (2007). Differences between Domestic Accounting Standards and IAS: Measurement, Determinants and Implications. Journal of Accounting and Public Policy, 26(2007), 1-38.

Fontes, A., Rodrigues, L. L., \& Craig, R. (2005). Measuring Convergence of National Accounting Standards with International Financial Reporting Standards. Accounting Forum, 29(4), 415436. https://doi.org/10.1016/j.accfor.2005.05.001

Haga, J., Siekkinen, J., \& Sundvik, D. (2015). Expert Systems with Applications Initial Stage Clustering when Estimating Accounting Quality Measures with Self-organizing Maps. Expert Systems with Applications, 42(2015), 8327-8336.

Hsu, C. C., \& Sandford, B. A. (2007). The Delphi Technique: Making Sense of Consensus. Practical Assessment Research \& Evaluation, 12(10). Available: $\mathrm{http}: / /$ pareonline.net/getvn.asp?v=12\&n=10 
International Federation of Accountants (2016). IFAC Global SMP survey: 2016 Results. Available: https://www.ifac.org/knowledge-gateway/contributing-global-economy/publications/2016ifac-global-smp-survey-report-summary

Likert, R. (1932). A technique for the Measurement of Attitudes Pt2. Archives of Psychology, (140)22, 21-55.

Malinić, D., Novićević, B., Malinić, S., \& Stojanović, R. (2016). Računovodstveni regulatorni okvir i kvalitet finansijskog izveštavanja u Republici Srbiji - istraživačka studija. Belgrade: Serbian Association of Accountants and Auditors. Available: http://www.srrs.rs/hitno/studijal.html?v=1

Milutinović, S. (2016). Savremeni trendovi u harmonizaciji finansijskog izveštavanja. PHD thesis. University in Novi Sad. [online] Available: https://nardus.mpn.gov.rs/bitstream/handle/ 123456789/4678/Disertacija387.pdf?sequence=7\&isAllowed=y [Accessed in March 2020].

Milutinović, S. (2014). Stepen konvergencije računovodstvene regulative u Srbiji sa međunarodnom regulativom. Računovodstvo, 9-10/2014, 40-55.

Ministry of Finance of the Republic of Serbia (2019). Law on Accounting. Official Gazette of the Republic of Serbia, No. 62/2013, 30/2018 and 73/2019. [online] Available: https:/www.mfin.gov.rs/UserFiles/File/zakoni/2013/ZAKON\%20O\%20RACUNOVODST VU.pdf [Accessed in March 2020].

Ministry of Finance of the Republic of Serbia (2019). Law on Auditing. Official Gazette of the Republic of Serbia, No. 73/2019. [online] Available: http:/www.mfin.gov.rs/UserFiles/File/ zakoni/2018/Zakon\%20o\%20reviziji.pdf [Accessed in March 2020].

Ministry of Finance of the Republic of Serbia (2017). Opinion on the application of the selected accounting regulations in continuity pursuant to Article 21, paragraph 3 and Article 22, paragraph 3 of the Law on Accounting. No. 011-00-158/2017-16 of 1st March 2017, pp. 204206. Available: http://www.mfin.gov.rs/UserFiles/File/bilten\%20strucna\%20misljenja/ 2017/BILTEN\%203-2017.pdf

Nerurkar, P., Shirke, A., Chandane, M., \& Bhirud, S. (2018). Empirical Analysis of Data Clustering $\begin{array}{lllll}\text { Algorithms. } & \text { Procedia } & \text { Computer } & \text { Science, } & 125,\end{array}$ https://doi.org/10.1016/j.procs.2017.12.099

Nunnally, J. C. (1979). Psychometric Theory. New York: McGraw-Hill.

Okoli, C., \& Pawlowski, S. D. (2004). The Delphi Method as a Research Tool: An Example, Design Considerations and Applications. Information \& Management, 42(2004), 15-29. https://doi.org/10.1016/j.im.2003.11.002

Palacios-Manzano, M., \& Martinez-Conesa, I. (2014). Assessing the Impact of IFRS Adaptation on Earnings Management: An Emerging Market Perspective. Transformations in Business \& Economics, 31, 21-40.

Pavot, W., Diener, E., Colvin, C. R., \& Sandvik, E. (1991). Further Validation of the Satisfaction with Life Scale. Journal of Personality Assess, 57(1), 149-161.

Peng, S., \& van der Laan Smith, J. (2010). Chinese GAAP and IFRS: An Analysis of the Convergence Process. Journal of International Accounting, Auditing and Taxation, 19(2010), 16-34. https://doi.org/10.1016/j.intaccaudtax.2009.12.002

Qu, X., \& Zhang, G. (2008). Measuring the Convergence of National Accounting Standards with International Financial Reporting Standards: The Application of Fuzzy Clustering Analysis. The International Journal of Accounting, 45(3), 334-355. https://doi.org/10.1016/j.intacc.2010.06.008

Quah, C.H. (2014). Revisiting Business Cycles in the Eurozone: A Fuzzy Clustering and Discriminant Approach. Acta Oeconomica, 64(2), 161-180. https://doi.org/10.1556/AOecon.64.2014.2.2

Rezaee, Z., Smith, L. M., \& Szendi, J. Z. (2010). Convergence in Accounting Standards: Insights from Academicians and Practitioners. Advances in Accounting, 26(2010), 142-154. https://doi.org/10.1016/j.adiac.2010.01.001 
Socoliuc, M., Bostan, I., Grosu, V., Hlaciuc, E., Mihalciuc, C., Colbu, I., \& Mates, D. (2012). Compatibility of the Romanian Accounting System with the Standard IAS/IFRS System. Strategic Management, 17(2012), 54-63. Available: http://www.ef.uns.ac.rs/sm/archive/SM2012_3.pdf

Syakur, M. A., Khotimah, B. K., Rochman, E. M. S., \& Satoto, B. D. (2018). Integration K-Means Clustering Method and Elbow Method For Identification of The Best Customer Profile Cluster. In: IOP Conference Series: Materials Science and Engineering. p. 012017. https://doi.org/10.1088/1757-899X/336/1/012017

Tabachnick, B., \& Fidell, L. (2013). Using Multivariate Statistics. Boston: Pearson.

Tan, P. N., Steinbach, M., \& Kumar, V. (2007). Introduction to Data Mining. Boston: Pearson.

The European Parliament and the Council of the European Union (2004). Regulation (EC) No 726/2004 of the European Parliament and of the Council. Official Journal of European Union, L 136, 30.4.2004. Available: https://eur-lex.europa.eu/legalcontent/EN/TXT/PDF/?uri=CELEX:32004R0726\&from=en

Thiprungsri, S., \& Vasarhelyi, M. (2011). Cluster Analysis for Anomaly Detection in Accounting Data: An Audit Approach. The International Journal of Digital Accounting Research, 11(2011), 69-84. https://doi.org/10.4192/1577-8517-v11

Trninić, J., Grljević, O., \& Serdar, A.M. (2011). Utilization of intelligent methods and techniques for customer knowledge management. The Perspectives of Innovations, Economics and Business, 7(1), 48-50.

Večerskienė, G., Valančienè, L., \& Boguslauskas, V. (2008). Training Accounting Specialists at Kaunas University of Technology Economics and Management Faculty: Past, Present and Perspectives. Inzinerine Ekonomika - Engineering Economics, 4(59), 9-17.

Weka - The workbench for machine learning (2019). University of Waikato. Available at: https://www.cs.waikato.ac.nz/ml/weka/

Yang, H., \& Yuan, C. (2019). Research on K-Value Selection Method of K-Means. Multidisciplinary Scientific Journal, 2(2), 226-235. https://doi.org/10.3390/j2020016

\section{OCENA RAČUNOVODSTVENE REGULATIVE U REPUBLICI SRBIJI: PRIMENA KLASTER ANALIZE}

Apstrakt: U fokusu rada je otkrivanje skrivenih obrazaca u stavovima računovođa, kako bi se identifikovali nedostaci zakonske računovodstvene regulative i istražilo njihovo mišljenje o međunarodnoj i zakonskoj računovodstvenoj regulativi. Podaci prikupljeni putem upitnika segmentirani su primenom data mining tehnike klasterovanja. Identifikovali smo različite grupe računovođa sa specifičnim obrascima u pogledu iskazanih stavova o oba nivoa računovodstvene regulative, kao i različite grupe računovođa sa specifičnim obrascima $u$ pogledu načina pribavljanja informacija. Rezultati ukazuju na preovlađujuće negativno mišljenje o kvalitetu zakonske računovodstvene regulative, kao i na postojanje razlika u navikama $\mathrm{i}$ stavovima sertifikovanih i nesertifikovanih računovođa, odnosno računovođa koji koriste/ ne koriste Međunarodne standarde finansijskog izveštavanja. Razvijena su četiri modela i njih smo koristili kao osnovu prilikom predlaganja informacionog modela koji bi mogao umanjiti negativne stavove o računovodstvenoj regulativi u nacionalnoj ekonomiji. Ključne tačke predloženog modela su uvođenje obavezne kontinuirane profesionalne edukacije, sertifikovanja svih računovođa, kao i aktivnosti na popularizaciji i dostupnosti međunarodne računovodstvene regulative.

Ključne reči: Međunarodni standardi finansijskog izveštavanja, računovodstvena regulativa, kvalitet, računovođe, klasterovanje, data mining. 


\section{Authors' biographies}

Sunčica Milutinović, $\mathrm{PhD}$, is an Assistant Professor at the University of Novi Sad, Faculty of Economics in Subotica. She is the author of 100 scientific papers in the field of accounting, corporate financial reporting and international accounting legislation. She is editorial board member in the international journal "Facta Universitatis, Series: Economics and Organization", organizational committee member at the International Conference on Interdisciplinary Management Research (Opatija, Croatia), and scientific board member at the Tourism International Scientific Conference (Vrnjačka Banja, Serbia). She is also engaged as an exam invigilator at the Ryerson University, The G. Raymond Chang School of Continuing Education (Toronto, Canada). She is a reviewer in many national scientific journals and has participated at over 40 conferences in the country and abroad.

Olivera Grljević, $\mathrm{PhD}$, is an Assistant Professor at the University of Novi Sad, Faculty of Economics in Subotica. Her research interests are focused on sentiment analysis, text mining, and data mining. Her current research projects include developing resources for natural language processing for the Serbian language, application of machine learning and data mining towards the extraction of business knowledge from unstructured data, and image processing with the application of deep learning neural networks. She has participated in 8 researched projects and authored more than 50 scientific or professional papers. She is engaged as a reviewer in the journals Knowledge Management Research \& Practice (SSCI, IF 1.485), Electronic Library (SSCI, IF 0.56) and Computer Science and Information Systems (SCI, IF 0.620).

Dragomir Dimitrijević, $\mathrm{PhD}$, is an Associate Professor at the University of Kragujevac, Faculty of Economics, where he received his $\mathrm{PhD}$ in the narrow scientific field of Accounting, Auditing, and Business Finance. He teaches the undergraduate and master studies of the Faculty, the subjects of Financial Accounting and Forensic Accounting. Areas of his scientific interest are Financial Reporting, Frauds in Business, and Forensic Accounting. As author and co-author he published a number of papers and participated in many scientific projects and educations. 